\title{
PELAKSANAAN KEGIATAN RENCANA OPERASI KAPAL PATROLI DI PANGKALAN PENJAGAAN LAUT DAN PANTAI (PPLP) KELAS II TANJUNG PERAK SURABAYA
}

\author{
Purwantini $\mathrm{S}^{1^{*}}$, Wahyuni, ${ }^{2}$ \\ ${ }^{1,2}$ Program Studi Ketatalaksanaan Angkutan Laut dan Kepelabuhanan Politeknik Ilmu Pelayaran \\ Semarang \\ Jln. Singosari 2A Semarang \\ Email: purwantinisri66@gmail.com
}

\begin{abstract}
Abstrak
Pangkalan Penjagaan Laut dan Pantai adalah Unit Pelaksana Teknis yang berada di bawah dan bertanggung jawab kepada Direktur Jenderal Perhubungan Laut. Mempunyai tugas melaksanakan kegiatan penjagaan, penyelamatan, pengamanan dan penertiban serta penegakan peraturan perundang-undangan di bidang pelayaran. Menindaklanjuti Keputusan Direktur Jenderal Perhubungan Laut No. KL.006/1/8/DJPL-13 perihal Pedoman Penyusunan Rencana Operasi Kapal Patroli Pangkalan Penjagaan Laut dan Pantai mengharuskan menyusun rencana operasi secara rutin setiap tahun dalam rangka pelaksanaan tugas pokok dan fungsi Pangkalan Penjagaan Laut dan Pantai . Rencana operasi ini merupakan evaluasi dan pengembangan dari rencana operasi tahun sebelumnya. Dalam penelitian ini, penulis melaksanakan pengamatan secara langsung terhadap kegiatan rencana operasi kapal patroli dan terdapat permasalahan yaitu kurangnya Sumber Daya Manusia (SDM) dan kompetensinya dan kondisi kapal yang minim. Tujuan Penelitian ini untuk mengetahui pelaksanaan kegiatan rencana operasi kapal patroli di Pangkalan Penjagaan Laut dan Pantai (PPLP) kelas II Tanjung Perak Surabaya, faktor yang menjadi kendala dalam pelaksanaan tugas patrol dan upaya untuk mengatasi kendala tersebut. Metode penelitian deskriptif kualitatif digunakan dengan teknik pengumpulan data melalui observasi dan wawancara dan untuk menganalisis data menggunakan teknik deskripsi analitis. Teknik keabsahan data menggunakan triangulasi metode, dengan melakukan pengecekan hasil penelitian dengan teknik pengumpulan data yang berbeda yaitu observasi, wawancara dan dokumentasi. Hasil penelitian menunjukkan bahwa hambatan dalam pelaksanaan patroli operasi kapal antara lain kurangnya sumber daya manusia dan kompetensinya dan kondisi kapal yang minim, Upaya dalam mengatasi kendala tersebut dilakukan dengan membuka pelatihan diklat keterampilan dan updating Sertifikat dan pembaharuan kapal patroli dan perawatan fasilitas kapal.
\end{abstract}

Kata Kunci: Kapal Patroli, Pangkalan Penjagaan Laut, Rencana Operasi

\section{PENDAHULUAN}

Indonesia adalah negara maritim sekaligus negara kepulauan terbesar yang ada di Asia, bahkan di dunia. Selain sebagai negara kepulauan, Indonesia juga memiliki karakteristik laut yang cukup unik yang digunakan sebagai alur transportasi nasional maupun internasional. Pelabuhan merupakan tempat untuk memberikan pelayanan sandar dan labuh sebuah kapal, juga memberikan pelayanan bongkar muat barang dan penumpang. Namun selain tugas dan fungsinya, Pelabuhan juga diwajibkan memberikan rasa nyaman dan keamanan bagi kapal kapal yang akan masuk dan keluar pelabuhan. Hal ini tertuang dalam Undang-Undang No. 17 Tahun 2008 tentang Pelayaran pada pasal 276 ditegaskan, bahwa pentingnya keselamatan dan keamanan berlayar serta kelancaran berlalu lintas di perairan tertentu dan pelabuhan. Peran sebagai penjaga laut dan pantai untuk memberikan rasa aman dan selamat diemban oleh Kesatuan Penjaga Laut dan Pantai (KPLP) dengan tugasnya adalah melakukan 1) pengawasan keselamatan dan keamanan pelayaran 2) melakukan pengawasan, pencegahan, penecemaran di laut 3) pengawasan dan penertiban kegiatan serta lalu lintas kapal 4) 
pengawasan dan penertiban kegiatan salvage, pekerjaan bawah air, serta eksplorasi dan eksploitasi kekayaan laut 5) pengamanan sarana bantu navigasi pelayaran 6) mendukung pelaksanaan kegiatan pencarian dan pertolongan jiwa di laut. Dengan luasnya wilayah kerja pelabuhan Tanjung Perak ( termasuk alur pelayaran barat dan timur Surabaya) membutuhkan kinerja aparat yang baik untuk menjamin keselamatan dan keamanan pelayaran di perarian tersebut. Dalam upaya mewujudkan keamanan dan keselamatan maka Indonesia membentuk Kesatuan Penjagaan Laut dan Pantai (KPLP). Struktur KPLP terdiri dari Direktorat KPLP yang merupakan unit Eselon II dibawah Direktorat Jenderal Perhubungan Laut Kementerian Perhubungan Republik Indonesia dan Unit Pelaksana Teknis (UPT) Pangkalan Penjagaan Laut dan Pantai (PPLP) yang tersebar di Indonesia. PPLP mempunyai tugas melaksanakan kegiatan penjagaan, penyelamatan, pengamanan dan penertiban serta penegakan peraturan di bidang pelayaran di perairan laut dan pantai yang diatur dalam Keputusan Menteri Perhubungan No. KM 65 tahun 2002 tentang Organisasi dan Tata Kerja Pangkalan Penjagaan Laut dan Pantai.

Menindaklanjuti Keputusan Direktur Jenderal Perhubungan Laut No. KL.006/1/8/DJPL-13 perihal Pedoman Penyusunan Rencana Operasi Kapal Patroli Kesatuan Penjagaan Laut dan Pantai (KPLP) pada Unit Pelaksana Teknis (UPT) Direktorat Jenderal Perhubungan Laut mengharuskan Pangkalan Penjagaan Laut dan Pantai (PPLP) menyusun rencana operasi secara rutin dalam rangka pelaksanaan tugas pokok dan fungsi Pangkalan Penjagaan Laut dan Pantai (PPLP).

Rencana operasi ini dilaksanakan setiap tahun secara rutin yang merupakan evaluasi dan pengembangan dari operasi tahun sebelumnya dan hanya akan melibatkan kapal-kapal Pangkalan Penjagaan Laut dan Pantai (PPLP) kelas II
Tanjung Perak Surabaya yang dimaksimalkan pada wilayah kerja yang menjadi tanggung jawabnya.

Perumusan masalah penelitian sebagai berikut :

1. Bagaimana pelaksanaan kegiatan rencana operasi kapal patroli di Pangkalan Penjagaan Laut dan Pantai (PPLP) kelas II Tanjung Perak Surabaya?

2. Apakah faktor yang menjadi kendala dalam pelaksanaan kegiatan rencana operasi kapal patroli di Pangkalan Penjagaan Laut dan Pantai (PPLP) kelas II Tanjung Perak Surabaya?

3. Upaya yang dilakukan untuk mengatasi kendala dalam pelaksanaan kegiatan rencana operasi kapal patroli di Pangkalan Penjagaan Laut dan Pantai (PPLP) kelas II Tanjung Perak Surabaya?

\section{LANDASAN TEORI}

1. Pengertian Perencanaan

Perencanaan menurut Richard L. Daft berarti mengidentifikasi berbagai tujuan untuk kinerja organisasi dimasa mendatang serta memutuskan tugas dan penggunaaan sumber daya yang diperlukan untuk mencapainya. perencanaan adalah tindakan yang dilakukan untuk menentukan tujuan perusahan.

Sedangkan menurut Robbins, perencanaan adalah suatu proses yang melibatkan penentuan sasaran atau tujuan organisasi, menyusun strategi menyeluruh untuk mencapai sasaran yang ditetapkan, dan mengembangkan hierarki rencana secara menyeluruh untuk mengintegrasikan dan mengkoordinasikan kegiatan.

Menurut George Pickett \& John J. Hanlon, pengertian perencanaan adalah proses dalam menentukan bagaimana mencapai suatu tujuan.

Dalam perencanaan diperlukan sebuah aspek aspek perencanaan,yakni :1)Suatu hasil dari pekerjaan perencanaan (outcome of planning), 2)Perangkat organisasi yang dipergunakan untuk melaksanakan pekerjaan perencanaan (mechanic of planning). 3)Sebuah proses atau 
langkah-langkah melakukan pekerjaan perencanaan (process of planning).

Perencanaan yang baik merupakan perencanaan yang menuntut adanya sistem monitoring, evaluasi dan reporting yang memadai berfungsi sebagai umpan balik untuk tindakan pengendalian terhadap deviasi-deviasi yang terjadi dalam usaha mempermudah dalam pengendalian merupakan salah satu upaya, yang dapat dilakukan adalah dengan cara membagibagi proses perencanaan ke dalam waktu atau periode periode tertentu.

\section{Macam perencanaan}

Ditinjau dari tingkatan rencana, maka perencanaan dibagi menjadi tiga macam yaitu :

\section{a. Perencanaan induk}

Perencanaan induk (master planning), apabila rencana yang dihasilkan lebih menitik beratkan pada aspek kebijakan, mempunyai ruang lingkup yang sangat luas serta berlaku untuk jangka waktu yang cukup panjang.

b) Perencanaan operasional Perencanaan operasional (operational planning), apabila rencana yang dihasilkan menitik beratkan pada aspek -aspek pedoman pelaksanaan yang akan dipakai sebagai petunjuk pada waktu melaksanakan kegiatan.

c) Perencanaan harianPerencanaan harian (day -to-day planning), apabila rencana yang dihasilkan telah disusun dengan rinci. Rencana harian biasanya disusun untuk program yang telah bersifat orang.

Rencana operasi adalah suatu usaha untuk menjalankan kegiatan dengan efektif dan efisien untuk mencapai tujuan. Termasuk rencana operasi ini yang merupakan evaluasi dan pengembangan dari operasi tahun-tahun sebelumnya dan hanya melibatkan kapal-kapal Pangkalan Penjagaan Laut dan Pantai (PPLP) Kelas II Tanjung Perak Surabaya yang dimaksimalkan pada wilayah kerja yang menjadi tanggung jawab Pangkalan Penjagaan Laut dan Pantai (PPLP).

Berdasarkan Keputusan Direktur Jenderal Perhubungan Laut No. KL.006/1/8/DJPL-13 perihal Pedoman Penyusunan Rencana Operasi Kapal Patroli Pangkalan Penjagaan Laut dan Pantai mengharuskan menyusun Rencana Operasi Kapal Patroli secara rutin setiap tahun dalam rangka pelaksanaan Tugas Pokok dan Fungsi Pangkalan Penjagaan Laut dan Pantai.

Ruang lingkup Rencana Operasi Pangkalan Penjagaan Laut dan Pantai (PPLP) Kelas II Tanjung Perak Surabaya terbatas hanya melibatkan kapal-kapal patroli di Pangkalan PPLP kelas II Tanjung Perak Surabaya. Operasi ini dilaksanakan tahun 2019 pada wilayah kerja PPLP kelas II Tanjung Perak Surabaya sesuai telegram Direktur Jenderal Perhubungan Laut No. 13/VIII/DV-05 tanggal 13 Agustus 2005 tentang Wilayah Kerja Pangkalan Penjagaan Laut dan Pantai.

3. Pengertian Kapal Patroli

Kapal Negara Patroli Kesatuan Penjagaan Laut dan Pantai Direktorat Jenderal Perhubungan Laut yang selanjutnya disebut Kapal Patroli adalah kapal milik negara yang digunakan oleh Direktorat Jenderal Perhubungan Laut yang diberi fungsi dan kewenangan sesuai dengan ketentuan peraturan perundangundangan untuk menegakkan hukum serta tugas-tugas Pemerintah lainnya di bidang pelayaran.

Kapal patroli Pangkalan Penjagaan Laut dan Pantai (PPLP) adalah milik Direktorat Jenderal Perhubungan Laut. Aset kapal patroli milik Direktorat Jenderal Perhubungan Laut sebanyak 39 (tiga puluh sembilan) kapal yang tersebar di seluruh Pangkalan Penjagaan Laut dan Pantai (PPLP) di Indonesia. Pembagian kapal patroli tersebut berdasarkan permintaan dan kebutuhan masing-masing pangkalan. PPLP kelas II Tanjung Perak Surabaya memiliki 5 (lima) unit kapal patroli yang terdiri dari kapal kelas I sebanyak 1 (satu) unit dan kapal kelas II sebanyak 1 (satu) unit dengan 
kondisi siap operasi serta kapal kelas III sebanyak 3 (tiga) unit dengan kondisi 2 (dua) unit siap terbatas dan 1 (satu) unit tidak difungsikan. Kapal patroli tersebut yaitu kapal kelas I (KN. Chundamani P.116), kapal kelas II (KN. Grantin P.211), kapal kelas III (KN. P.371, KN. P.329, dan yang tidak difungsikan KN. P.306).

4. Pengertian Pangkalan Penjagaan Laut dan Pantai (PPLP)

Kedudukan Direktorat Kesatuan Penjagaan Laut dan Pantai merupakan Unit Eselon II yang dipimpin oleh seorang Direktur. Direktorat Kesatuan Penjagaan Laut dan Pantai dibawah naungan Direktorat Jenderal Perhubungan Laut, Kementerian Perhubungan. Adapun struktur KPLP sendiri terdiri dari Direktorat KPLP dan Unit Pelaksana Teknis (UPT) Pangkalan Penjagaan Laut dan Pantai (PPLP) yang tersebar di Indonesia. Menurut Keputusan Menteri Perhubungan Nomor KM 65 Tahun 2002 tanggal 2 Oktober 2002 tentang Organisasi dan Tata Kerja Pangkalan Penjagaan Laut dan Pantai bahwa Pangkalan Penjagaan Laut dan Pantai adalah Unit Pelaksana Teknis di lingkungan Direktorat Jenderal Perhubungan Laut, yang berada di bawah dan bertanggung jawab kepada Direktur Jenderal Perhubungan Laut.

Pangkalan Penjagaan Laut dan Pantai (PPLP) mempunyai tugas melaksanakan kegiatan penjagaan, penyelamatan, pengamanan dan penertiban serta penegakan peraturan di bidang pelayaran di perairan laut dan pantai (Keputusan Menteri Perhubungan Nomor KM 65 Tahun 2002). Pembagian wilayah kerja pangkalan dibagi berdasarkan Keputusan Direktur Jenderal Perhubungan Laut No.13/VIII/DV-05 tanggal 13 Agustus 2005.

Kesatuan Penjagaan Laut dan Pantai memiliki 5 (lima) pangkalan utama yang tersebar di seluruh Indonesia. Kelas I yaitu PPLP Tanjung Priok (Jakarta), Kelas II yaitu PPLP Tanjung Uban (Kepulauan Riau), PPLP Bitung (Sulawesi Utara),
PPLP Tanjung Perak (Surabaya), dan PPLP Tual (Maluku).

\section{METODE}

Metode penelitian kualitatif menurut Syaodih Nana, (2007:60) adalah cara untuk mendeskripsikan dan menganalisis fenomena, peristiwa, aktivitas sosial, sikap kepercayaan, persepsi, pemikiran orang secara individual maupun kelompok.

\section{Tempat dan waktu penelitian}

Penelitian ini dilaksanakan pada tanggal 01 Juli 2019 hingga 31 Juli 2019 dan dilaksanakan di Kantor Pangkalan Penjagaan Laut dan Pantai (PPLP) kelas II Tanjung Perak Surabaya

\section{Sumber Data Penelitian}

Data Primer yang diperoleh dalam penelitian ini adalah dengan pengamatan secara langsung difokuskan pada kegiatan rencana operasi kapal patroli di Pangkalan Penjagaan Laut dan Pantai (PPLP) kelas II Tanjung Perak Surabaya. Sedangkan wawancara dilakukan pada narasumber yang berkompeten terkait dengan masalah penelitian. Narasumber yang diwawancarai yaitu Nakhoda KN. P. 329, Seksi Penyiap Bantuan dan SAR dan Seksi Pengadministrasian Program Operasi.

Data sekunder dalam penelitian ini berupa bahan hukum primer yaitu Undangundang no. 17 tahun 2008 tentang Pelayaran dan bahan hukum sekunder yang terdiri dari; Peraturan Menteri Perhubungan No. 73 tahun 2017 tentang Peta Jabatan dan Uraian Jenis Kegiatan Jabatan di Lingkungan Unit Pelaksana Teknis Direktorat Jenderal Perhubungan Laut Kementerian Perhubungan; Keputusan Menteri Perhubungan No. 65 tahun 2002 tentang Organisasi dan Tata Kerja Pangkalan Penjagaan Laut dan Pantai; Keputusan Menteri Perhubungan No. 60 tahun 2010 tentang Organisasi dan Tata Kerja Kementerian Perhubungan; Peraturan Direktur Jenderal Perhubungan Laut No. HK.205/8/13DJPL/2019 tentang Pedoman Teknis Kriteria Penempatan Kapal Negara Patroli Kesatuan Penjagaan Laut dan Pantai 
Direktorat Jenderal Perhubungan Laut; Keputusan Direktur Jenderal Perhubungan Laut No. KL.006/1/8/DJPL-13 tentang Pedoman Penyusunan Rencana Operasi Kapal Patroli Kesatuan Penjagaan Laut dan Pantai; dan Keputusan Direktur Jenderal Perhubungan Laut No. 13/VIII/DV-05 tentang Wilayah Kerja Pangkalan Penjagaan Laut dan Pantai.

\section{Teknik Pengumpulan Data}

\section{Dalam Penelitian}

kualitatif, pengumpulan data dilakukan di dalam berbagai setting, berbagai sumber, dan berbagai cara.

Dari sisi setting maka data dikumpulkan dalam kondisi yang alamiah (natural setting). Sementara dari sisi sumber maka data dikumpulkan dari berbagai sumber yaitu sumber primer, dan sumber sekunder. Selanjutnya jika dilihat dari sisi cara atau teknik pengumpulan data lebih banyak dilakukan dengan pengamatan (observasi), wawancara mendalam (in depth interview) dan dokumentasi.

Pengamatan atau observasi merupakan suatu unsur penting dalam penelitian kualitatif, observasi dalam konsep yang sederhana adalah sebuah proses atau kegiatan awal yang dilakukan oleh peneliti untuk bisa mengetahui kondisi, realitas lapangan penelitian.

Observasi dalam penelitian kualitatif sebagaimana yang diungkapkan oleh Satori Djam'an dan Komariah Aan, (2012:105) adalah pengamatan langsung terhadap objek untuk mengetahui keberadaan objek, situasi, konteks dan maknanya dalam upaya mengumpulkan data penelitian

Lebih lanjut observasi sebagaimana yang diungkapkan oleh Maleong (2011:175) adalah pengamatan digunakan untuk mengoptimalkan kemampuan peneliti dari segi motif,kepercayaan, perhatian, perilaku tak sadar, kebiasaan dan sebagainya. Observasi sesungguhnya dilakukan dengan memiliki tujuan atau manfaat.

Data diperoleh melalui observasi, wawancara, studi dokumentasi, dan studi pustaka Adapun teknik pengumpulan data yang penulis digunakan yaitu: a. Observasi

Teknik observasi digunakan dengan tujuan untuk dapat mengerti keadaan objek yang dijadikan topik secara menyeluruh dan langsung untuk memberi kesesuaian antara keterangan-keterangan yang diperoleh. Pengamatan di-lakukan dengan cara mengamati langsung terhadap kegiatan rencana operasi kapal patroli.

b. Wawancara

Dalam hal ini, dilakukan wawancara dengan beberapa narasumber yaitu:

1) Capt. Sitti Hajrah (Nakhoda KN. P. 329) Sebagai pihak yang bertanggung jawab atas segala kegiatan di atas kapal patroli.

2) Bapak Poniman (Seksi Penyiap Bantuan Musibah dan SAR)

Sebagai pihak yang terkait dengan kegiatan kapal patroli.

3) Ibu Sri Handayani (Seksi Pengadministrasian Program Operasi).

\section{c. Dokumentasi}

Dalam teknik dokumentasi diperoleh data-data tentang Pangkalan Penjagaan Laut dan Pantai (PPLP) kelas II Tanjung Perak Surabaya, data kapal patroli dan data kegiatan Pangkalan Penjagaan Laut dan Pantai (PPLP) kelas II Tanjung Perak Surabaya.

d. Studi Kepustakaan

Pada penelitian ini menggunakan studi kepustakaan dengan mengumpulkan informasi dari buku-buku, peraturan perundang-undangan.

\section{Teknik Keabsahan Data}

Teknik keabsahan data yang digunakan penulis dalam penelitian ini adalah teknik Triangulasi. Penggunaan sejumlah metode pengumpulan data dalam suatu penelitian. Triangulasi diperlukan karena setiap teknik pengumpulan data memiliki kelemahan dan keunggulannya sendiri. Peneliti melakukan pengecekan derajat kepercayaan melalui teknik triangulasi dengan metode. Dengan memadukan sedikitnya tiga metode, yaitu pengamatan atau observasi, wawancara, dan 
penulusuran dokumen, maka teknik tersebut akan saling menutupi kelemahan satu sama lain.

5. Teknik Analisis Data

Analisis data dilakukan dalam tiga tahap yaitu reduksi data, penyajian data dan penarikan kesimpulan. Teknik analisis yang digunakan dalam penelitian ini adalah deskriptif kualitatif.

\section{HASIL DAN PEMBAHASAN}

1. Pangkalan Penjagaan Laut dan Pantai Pangkalan Penjagaan Laut dan

Pantai (PPLP) Menurut Keputusan Menteri Perhubungan Nomor KM 65 tahun 2002 tanggal 2 Oktober 2002 tentang Organisasi dan Tata Kerja Pangkalan Penjagaan Laut dan Pantai bahwa Pangkalan Penjagaan Laut dan Pantai (PPLP) adalah Unit Pelaksana Teknis di lingkungan Direktorat Jenderal Perhubungan Laut yang berada dibawah dan bertanggung jawab kepada Direktur Jenderal Perhubungan Laut. Pangkalan Penjagaan Laut dan Pantai (PPLP) mempunyai tugas melaksanakan kegiatan penjagaan, penyelamatan, pengamanan, dan penertiban serta penegakan peraturan perundang-undangan dibidang pelayaran di perairan laut dan pantai. Memiliki visi yaitu menciptakan keselamatan transportasi yang aman dan melindungi lingkungan maritim di seluruh wilayah perairan laut dan pantai Indonesia. Dan misi yaitu mewujudkan pengawasan transportasi laut yang handal sesuai standar nasional maupun internasioanl dengan meningkatkan keselamatan, pengamanan, ketertiban dan penegakan negara dibidang pelayaran di seluruh wilayah perairan laut dan pantai Indonesia. Pangkalan Penjagaan Laut dan Pantai (PPLP) memiliki semboyan "Dharma Jala Praja Tama" yang artinya "sebagai insan bahari selalu berusaha menjalankan pengabdian yang terbaik untuk bangsa dan negara".

Tugas dan Fungsi Pangkalan Penjagaan Laut dan Pantai (PPLP)

1. Undang-undang No. 17 Tahun 2008 Tentang Pelayaran
Pasal 276

a. Untuk menjamin terselenggaranya keselamatan dan keamanan di laut dilaksanakan fungsi penjagaan dan penegakan peraturan perundang-undangan di laut dan pantai.

b. Pelaksanaan1fungsi sebagaimana dimaksud pada ayat (1) dilakukan oleh penjaga laut dan pantai.

c. Penjaga laut dan pantai sebagaimana1dimaksud pada ayat (2) dibentuk dan bertanggung jawab kepada1Presiden dan secara teknis operasional dilaksanakan oleh Menteri.

\section{Pasal 277}

a. Dalam melaksanakan fungsi sebagaimana dimaksud dalam Pasal 276 ayat (1) penjaga laut dan pantai melaksanakan tugas;

1) Melakukan pengawasan keselamatan dan keamanan pelayaran;

2) Melakukan pengawasan, pencegahan, dan penanggulangan pencemaran di laut;

3) Pengawasan dan penertiban 1 kegiatan serta lalu lintas kapal;

4) Pengawasan dan penertiban 1 kegiatan salvage, pekerjaan bawah air, serta eksplorasi dan eksploitasi 1 kekayaan laut;

5) Pengamanan sarana 1 bantu navigasi pelayaran; dan

6) Mendukung pelaksanaan kegiatan pencarian dan pertolongan 1 jiwa di laut.

b. Dalam melaksanakan fungsi sebagaimana dimaksud dalam Pasal 276 ayat (1) penjaga laut dan pantai melaksanakan koordinasi untuk: 
1) Merumuskan dan menetapkan kebijakan umum penegakan hukum di laut;

2) Menyusun kebijakan dan standar prosedur operasi penegakan hukum di laut secara terpadu;

3) Kegiatan penjagaan, pengawasan, pencegahan, dan penindakan pelanggaran hukum serta pengamanan pelayaran dan pengamanan aktivitas masyarakat dan Pemerintah di wilayah perairan Indonesia; dan

4) Memberikan dukungan teknis administrasi di bidang penegakan hukum di laut secara terpadu.

Pasal 278

c. Dalam melaksanakan tugas sebagaimana dimaksud dalam Pasal 277, penjaga laut dan pantai mempunyai kewenangan untuk:

1) Melaksanakan patroli di laut;

2) Melakukan 1 pengejaran seketika (hot pursuit);

3) Memberhentikan dan memeriksa 1 kapal di laut; dan

4) Melakukan 1 penyidikan.

d. Dalam melaksanakan kewenangan sebagaimana dimaksud pada ayat (1) huruf d, penjaga laut dan pantai melaksanakan tugas sebagai Pejabat Penyidik Pegawai Negeri Sipil sesuai dengan ketentuan Peraturan Perundangundangan.

1) Peraturan Menteri Perhubungan No. KM. 60 Tahun 2010 tentang Organisasi dan Tata Kerja Kementerian Perhubungan

Pasal 277. Direktorat Jenderal Perhubungan Laut mempunyai tugas merumuskan serta melaksanakan kebijakan dan standarisasi teknis di bidang perhubungan laut.

Pasal 288.
Dalam melaksanakan tugas sebagaimana dimaksud dalam pasal 277, Direktorat Jenderal Perhubungan Laut menyelenggarakan fungsi:

1) Perumusan kebijakan di bidang perhubungan laut;

2) Pelaksanaan kebijakan1di bidang perhubungan laut;

3) Penyusunan norma, standar, prosedur, dan kriterialdibidang perhubungan laut;

4) Pelaksanaan pemberian 1 bimbingan teknis di bidang perhubungan laut; dan

5) Pelaksanaan administrasi Direktorat Jenderal Perhubungan Laut

Pasal 345

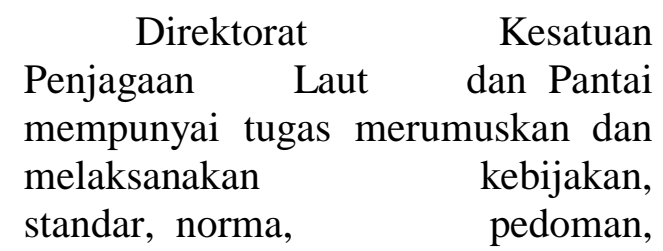
kriteria, dan prosedur, serta bimbingan teknis, evaluasi, dan pelaporan di bidang patroli dan pengamanan, pengawasan keselamatan dan Penyidik Pegawai Negeri Sipil (PPNS), tertib pelayaran, penanggulangan musibah, dan pekerjaan bawah air, sarana dan prasarana Penjagaan.

1) Keputusan Menteri Perhubungan No. KM 65 tahun 2002 tentang Organisasi dan Tata Kerja Pangkalan Penjagaan Laut dan Pantai

Pasal 2

Pangkalan Penjagaan Laut dan Pantai mempunyai tugas melaksanakan kegiatan penjagaan, penyelamatan, pengamanan, dan penertiban serta penegakan peraturan di bidang pelayaran di perairan laut dan pantai.

Pasal 3

Dalam melaksanakan 1 tugas sebagaimana dimaksud dalam Pasal 
2, Pangkalan1Penjagaan Laut dan Pantai menyelenggarakan fungsi:

1) Menyusun operasi;

2) Pelaksanaan operasi dan 1 penegakan Peraturan Perundangundnagan dibidang 1 pelayaran di perairan 1 laut dan pantai;

3) Pelaksanaan penyelidikan 1 dan penyidikan terhadap 1 tindak pidana pelayaran;

4) Pelaksanaan pengawasan 1 dan penertiban kegiatan salvage dan pekerjaan bawah air, penyelaman, 1

5) instalasi/eksplorasi dan eksploitasi, bangunan diatas dan dibawah air;

6) Pemberian bantuan 1 pencarian dan pertolongan musibah di laut dan penanggulangan 1 kebakaran;

7) Pelaksanaan pengamanan dan pengawasan sarana bantu navigasi 1 pelayaran serta penanggulangan 1 pencemaran di perairan;

8) Pelaksanaan pengadaan, 1 pemeliharaan, perbaikan, dan dukungan 1 logistik;

9) Pelaksanaan urusan 1 administrasi dan kerumahtanggaan.

2. Pelaksanaan rencana kegiatan operasi kapal patrol di PPLP Kelas II Tanjung Perak Surabaya

Berikut rincian pengendali operasi:

a. Pimpinan/Penanggung Jawab Operasi : Kepala PPLP Kelas II Tanjung Perak Surabaya

b. Wakil Pimpinan Operasi : Kepala Urusan Tata Usaha

c. Lakhar Operasi : Kepala Sub Seksi Operasi

d. Perwira Operasi

Pengadministrasian Program Operasi e. Unsur Patroli : Komandan Kapal Patroli PPLP Kelas II Tanjung Perak Surabaya.

\section{Data Kerawanan Wilayah}

Data kerawanan wilayah dilakukan berdasarkan hal-hal / kasus/tindakan/kejadian yang dianggap "lawan" dan sekaligus pemetaan terhadap pihak-pihak lain yang dianggap "kawan" dalam pelaksanaan operasi sebagai berikut:

1) Pihak Lawan

Yang dianggap melakukan tindakan pelanggaran terhadap keselamatan dan keamanan pelayaran sebagaimana yang diamanatkan dalam Undangundang No. 17 tahun 2008 tentang Pelayaran, yang dapat berakibat pada terjadinya suatu musibah pelayaran yaitu tenggelam, karam, dan tubrukan di laut. Oleh sebab itu perlu dilawan, diantaranya:

a. Pelanggaran kelengakapan dokumen dan surat-surat kapal;

b. Pencurian sarana bantu navigasi pelayaran;

c. Pemuatan yang berlebihan (overload);

d. Pengawakan yang tidak sesuai;

e. Olah gerak tanpa ijin;

f. Pelanggaran terhadap manajemen keselamatan kapal (ISM Code);

g. Pelanggaran terhadap manajemen keselamatan kapal dan fasilitas pelabuhan (ISPS Code); dan

h. Pelanggaran terhadap peraturan lainnya.

2) Pihak Kawan

Yang dianggap sebagai kawan adalah pihak-pihak yang mendukung, berkoordinasi, diminta bantuannya selama berlangsungnya operasi, yaitu:

a. TNI AL; 
b. Bakorkamla Koordinasi

(Badan Laut);

c. Polair;

d. KKP

(Kementerian

Kelautan dan Perikanan);

e. Bea dan Cukai;

f. Imigrasi; dan

g. Karantina.

Daerah atau perairan yang direncanakan sebagai lokasi adalah wilayah kerja yang menjadi tanggung jawab PPLP kelas II Tanjung Perak Surabaya sesuai Telegram Dirjen Hubla No. 13/VIII/DV05 tanggal 13 Agustus 2005 tentang Wilayah Kerja Pangkalan Penjagaan Laut dan Pantai. Didalam telegram tersebut menjelaskan tentang wilayah kerja PPLP kelas II Tanjung Perak Surabaya yang disebutkan dengan koordinat lintang dan bujur. Setiap koordinat lintang dan bujur tersebut akan membentuk suatu peta kecil yang nantinya peta kecil tersebut jika digabungkan menjadi satu akan membentuk suatu koordinat wilayah. Koordinat wilayah ini yang menjadi wilayah Kerja PPLP kelas II Tanjung Perak Surabaya. Berikut wilayah kerja:

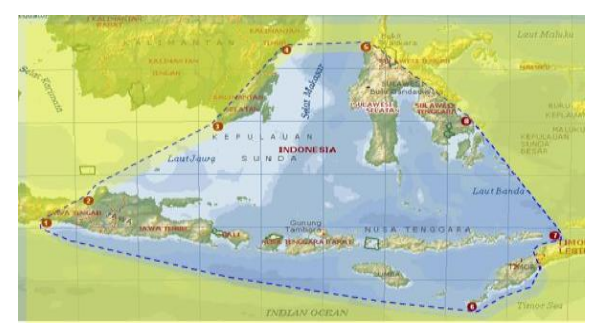

Gambar 1 Wilayah Kerja PPLP kelas II Tanjung Perak Surabaya
Batas koordinat wilayah kerja PPLP kelas II Tanjung Perak Surabaya meliputi seluruh wilayah perairan Provinsi Jawa Timur, Provinsi Kalimantan Selatan, Provinsi Bali, Provinsi Nusa Tenggara Barat, Provinsi Nusa Tenggara Timur, Provinsi Sulawesi Selatan dan sebelah barat Provinsi Sulawesi Tenggara.

\section{Dukungan Operasi}

Dukungan utama pelaksanaan operasi adalah kapal patroli kelas I, II, dan III yang dimiliki oleh PPLP kelas II Tanjung Perak Surabaya. Kapal patroli yang dimiliki oleh PPLP kelas II Tanjung Perak Surabaya sebanyak lima unit kapal patroli yang terdiri dari kapal kelas I (satu) sebanyak satu unit yaitu KN. Chundamani P. 116 dan kapal kelas II (dua) sebanyak satu unit yaitu KN. Grantin P. 211 dengan kondisi siap operasi serta kapal kelas III (tiga) sebanyak tiga unit dengan kondisi dua unit siap terbatas yaitu KN. P. 371 dan KN. P. 329 dan satu unit tidak difungsikan yaitu KN. P. 306.

\section{Pembahasan Masalah}

a. Bagaimana pelaksanaan kegiatan rencana operasi kapal patroli di Pangkalan Penjagaan Laut dan Pantai (PPLP) kelas II Tanjung Perak Surabaya?

Konsep pelaksanaan kegiatan rencana operasi ini yang dilaksanakan oleh PPLP kelas II Tanjung Perak Surabaya tahun 2019 adalah melaksanakan tugas pokok dan fungsi sesuai Keputusan Menteri Perhubungan No. KM 65 tahun 2002 tanggal 2 Oktober 2002 serta Undangundang No. 17 tahun 2008 tentang Pelayaran. Berikut adalah pelaksanaan dan pelaporan operasi:

1) Pelaksanaan Operasi :
a. Komandan Kapal Negara mengadakan koordinasi dengan seksi operasi dalam rangka pelaksanaan tugas operasi.
b. Komandan Kapal Negara melaksanakan operasi di


wilayah kerja/sektor sesuai SPB

(Surat Perintah Berlayar) masing-masing.

c. Komandan Kapal Negara melaksanakan operasi sesuai rencana dan pola yang telah ditetapkan.

2) Pelaporan Operasi :

Sistem pelaporan operasi dikategorikan atas pelaporan posisi kapal selama operasi dan pelaporan hasil operasi.

a. Seluruh unsur kapal patroli diwajibkan melaporkan posisi tengah

b. Hari dilaporkan setiap jam 12.00 waktu setempat sesuai sistem pelaporan dengan menggunakan jenis alat komunikasi yang sesuai dengan tata urut pelaporan.

c. Laporan hasil operasi disampaikan pada kesempatan pertama setiap hari sesuai dengan daerah operasi kepada Kepala PPLP.

d. Sistem pelaporan berpedoman pada prosedur yang berlaku di PPLP.

b. Apakah faktor yang menjadi kendala dalam pelaksanaan kegiatan rencana operasi kapal patroli di Pangkalan Penjagaan Laut dan Pantai (PPLP) kelas II Tanjung Perak Surabaya?

Kegiatan operasi ini cukup padat mengingat wilayah operasi yang cukup luas. Wilayah operasi tersebut menjadi tanggung jawab masing-masing kapal patroli yang bertugas di lokasi tersebut. Semakin ramai dan banyaknya kegiatan di perairan tepatnya di wilayah operasi PPLP kelas II Tanjung Perak Surabaya menyebabkan semakin ketat dan sigap pengawasan yang harus dilakukan. Dalam pelaksanaan kegiatan rencana kapal patroli ini penulis menemukan beberapa hambatan dalam pelaksanaannya yaitu:

1. Kurangnya Sumber Daya Manusia (SDM) dan Kompetensinya
Tabel 4.1. kekurangan Sumber Daya Manusia (SDM)

\begin{tabular}{|l|l|l|l|}
\hline Nama Kapal & $\begin{array}{l}\text { Jml Kru } \\
\text { Ideal }\end{array}$ & $\begin{array}{l}\text { Jml Kru } \\
\text { di } \\
\text { Lapangan }\end{array}$ & $\begin{array}{l}\text { Jumlah } \\
\text { Kekurangan }\end{array}$ \\
\hline $\begin{array}{l}\text { KN. } \\
\text { Chundamani } \\
\text { P. } 116\end{array}$ & 25 orang & 24 orang & 1 orang \\
\hline $\begin{array}{l}\text { KN. Grantin } \\
\text { P. 211 }\end{array}$ & 22 orang & 18 orang & 4 orang \\
\hline KN. P. 371 & 16 orang & 8 orang & 8 orang \\
\hline KN. P. 329 & 16 orang & 8 orang & 8 orang \\
\hline
\end{tabular}

Sumber Daya Manusia (SDM) memegang peran penting dalam kegiatan ini. Karena sumber daya manusia adalah pelaksana dimana lancarnya suatu kegiatan ditentukan oleh kekuatan personilnya. Personil ini menjadi acuan bagaimana kegiatan itu berlangsung. Dalam mengemban tugas negara sebagai penjaga keamanan dan keselamatan pelayaran, personil ini menjadi garda terdepan yang mengemban tugas sebagai penegak hukum di bidang keselamatan pelayaran. Maka dari itu, profesionalitas personil sangat diperlukan guna mengatasi permasalahan dan segala kegiatan di lapangan. Dalam hal ini personil yang dimaksud adalah kru kapal patroli di PPLP kelas II Tanjung Perak Surabaya. Setiap kapal patroli memiliki jumlah kru kapal yang berbeda sesuai dengan jenis kapal patrolinya. Berikut tabel jumlah kru kapal patroli:

Data penelitian menunjukkan yang terjadi di lapangan, salah satu kapal patroli kelas III yang seharusnya diawaki oleh 16 orang kenyataannya hanya 8 orang saja, hal ini terlihat jika mengalami kekurangan personil. Jumlah pengawakan tersebut berdasarkan Peraturan Menteri No. 73 tahun 2017 tentang Peta Jabatan dan Uraian Jenis Kegiatan Jabatan di Lingkungan Unit Pelaksana Teknis di Lingkungan Direktorat Jenderal Perhubungan Laut Kementerian Perhubungan. Pengajuan perekrutan kru kapal telah dilakukan sesuai prosedur 
namun untuk terealisasinya permintaan tersebut membutuhkan waktu yang tidak bisa ditentukan. Maka dari itu pilihan untuk permintaan perekrutan kru tidak dapat menjadi pilihan utama sehingga harus mencari cara lain agar kegiatan operasi tetap berjalan. Selain itu, beberapa kru di atas kapal belum memiliki sertifikat keahlian yang sesuai dengan bidangnya. Contohnya, kru menempati jabatan di atas kapal sebagai penyelam namun belum memiliki sertifikat keahlian di bidang menyelam. Kru kapal tersebut seharusnya memerlukan pelatihan khusus untuk menunjang keterampilan dalam bertugas. Dengan adanya kru kapal yang memiliki pengalaman dan berkompeten dibidangnya, maka kegiatan operasi ini akan berjalan dengan lancar.

2. Kondisi Kapal yang Minim

Suatu kapal dinyatakan siap beroperasi jika kondisinya laiklaut. Namun pada kenyataannya di lapangan bagaimanapun kondisi kapal tetap harus beroperasi demi menjalankan tugas. Kondisi minim disini diartikan sebagai kondisi dimana kapal tersebut kurang dan terbatas. Baik kurang dalam segi perawatan, perbaikan, dan pembaharuan beberapa fasilitasnya maupun terbatas dalam beroperasi. Karena kekurangan itulah kapal tersebut menjadi tidak bisa bekerja secara maksimal.

Meskipun telah ada pembagian wilayah kerja namun kinerja kapal patroli tidak dapat maksimal. Contohnya kapal patroli kelas I adalah kapal yang memiliki wilayah kerja paling luas diantara kapal patroli yang lain. Karena wilayah kerja yang cukup luas dengan kondisi perairan yang tidak dapat ditebak misalnya gelombang tinggi, angin kencang, cuaca buruk, atau kondisi alam lainnya tidak sebanding dengan kondisi kapal yang tidak cukup kuat di keadaan tersebut. Sehingga dibutuhkan armada yang bertenaga lebih besar dengan kecepatan yang tinggi dan didukung dengan fasilitas lengkap dan canggih sehingga dapat melaksanakan kegiatan patroli dengan lancar. Namun kembali lagi jika kapal patroli ini adalah milik negara sehingga permintaan armada baru cukup sulit untuk dapat terealisasi.

Selain itu, bertambahnya waktu membuat suatu kondisi kapal patroli berkurang kualitasnya yang semakin lama semakin buruk termakan usia. Karena permintaan armada baru cukup sulit untuk teralisasi maka perlu pemanfaatan armada yang ada. Dengan kondisi armada tersebut, maka perlu adanya perawatan kapal sehingga meskipun usia kapal sudah lama namun masih layak pakai dan dengan adanya perawatan maka akan membantu jika ada kerusakan tidak akan sampai parah.

c. Upaya yang dilakukan untuk mengatasi kendala dalam pelaksanaan kegiatan rencana operasi kapal patroli di Pangkalan Penjagaan Laut dan Pantai (PPLP) kelas II Tanjung Perak Surabaya?

Untuk melancarkan kegiatan tersebut memerlukan usaha-usaha guna meningkatkan kinerja dari Sumber Daya Manusia (SDM) agar lebih terampil dan sigap jika terjadi suatu permasalahan atau kejadian yang membahayakan. Maka penulis akan menjelaskan mengenai upaya yang sebaiknya dilakukan oleh PPLP kelas II Tanjung Perak Surabaya agar rencana operasi ini berjalan dengan lancar.

1. Membuka pelatihan Diklat keterampilan dan Updating Sertifikat Untuk menunjang kinerja kru kapal patroli maka diperlukan pelatihan khusus sesuai bidang dan keahliannya. Diklat yang bisa diambil antara lain:
a. Rescue Team;
b. International Safety Management (ISM Code);
c. International Ship and Port Facility Security (ISPS Code);
d. Pekerjaan Bawah Air;
e. Menyelam;
f. Konstable (Menembak); dan
g. Pencegahan dan Penanggulangan Pencemaran Laut.


Penyelenggaraan diklat ini dapat digunakan untuk menambah pengetahuan dan pemahaman tugas di lapangan yang telah diberikan kepada kru kapal patroli. Tujuan pelatihan ini agar kru kapal patroli memahami dalam penanganan bekerja, pengetahuan tentang hukum, sertifikat, dan dokumen di atas kapal. Dan untuk kru yang telah memiliki sertifikat dapat updating sertifikatnya agar dapat digunakan untuk ke jenjang karir yang lebih tinggi. Lebih baik jika semua sertifikat yang dimiliki oleh kru kapal datanya disimpan dan diperbaharui setiap hari untuk mengecek jika ada sertifikat yang perlu diperpanjang sehingga memudahkan dalam proses perpanjangan.

Selain itu juga dapat melaksanakan latihan gabungan atau bersama dengan instansi lain yang terkait untuk menambah solidaritas dan menjaga kekompakan. Dan juga dapat mengikuti seminar yang berhubungan dengan kegiatan patroli guna menambah wawasan dan pemahaman. Mengikuti bimbingan teknis (bimtek) juga dapat menjadi pilihan untuk menciptakan sumber daya manusia yang professional dan handal dalam menjalankan fungsi tugas menjaga keamanan dan keselamatan pelayaran.

2. Pembaharuan Kapal Patroli dan Perawatan Fasilitas Kapal

Perawatan kapal patroli sangat penting untuk menjaga kualitas dari kapal patroli tersebut. Perawatan kapal dapat dilakukan dengan mematuhi periode waktu docking (pengedokan kapal) dengan melakukan pengedokan sesuai dengan jadwal yang ditentukan untuk pelaksanaan pemeliharaan dan pemeriksaan kapal. Selain itu dapat melakukan pemeriksaan pembaharuan (renewal survey) yang meliputi pemeriksaan kondisi struktur bangunan kapal, termasuk kulit luar bagian bawah kapal dan pemeriksaan permesinan dan perlengkapannya. Dan juga dapat dilakukan pemeriksaan antara (intermediate survey) yang meliputi pemeriksaan kondisi struktur kapal, pemeriksaan mesin dan perlengkapannya.

Penambahan fasilitas juga diperlukan untuk melancarkan kegiatan operasi ini. Namun jika penambahan fasilitas tidak memungkinkan maka melakukan perawatan adalah kuncinya. Fasilitas yang telah ada dirawat dan dijaga dengan baik. Jika ada kerusakan sekecil apapun maka segera diperbaiki sehingga tidak menimbulkan kerusakan yang lebih parah.

\section{KESIMPULAN}

Berdasarkan hasil penelitian dan uraian-uraian sebelumnya, maka dapat diambil kesimpulan sebagai berikut:

1) Kegiatan rencana operasi kapal patroli dilaksanakan oleh Pangkalan Penjagaan Laut dan Pantai kelas II Tanjung Perak Surabaya berdasarkan Keputusan Direktur Jenderal Perhubungan Laut No. KL.006/1/8/DJPL-13 tentang Pedoman Penyusunan Rencana Operasi Kapal Patroli Kesatuan Penjagaan Laut dan Pantai dan telah sesuai dengan tugas pokok dan fungsinya yaitu melaksanakan kegiatan penjagaan, penyelamatan, pengamatan dan penertiban serta penegakan peraturan di bidang pelayaran di perairan laut dan pantai menurut Keputusan Menteri Perhubungan No. KM. 65 tahun 2002 tentang Organisasi dan Tata Kerja Pangkalan Penjagaan Laut dan Pantai. Pelaksanaan kegiatannya berjalan cukup lancar namun ada beberapa kendala dalam pelaksanaannya yang menyebabkan kegiatan tersebut tidak dapat berjalan secara maksmimal. 
2) Kendala yang dihadapi oleh Pangkalan Penjagaan Laut dan Pantai kelas II Tanjung Perak Surabaya yaitu personil kapal yang sedikit dan kurang berkompeten di bidangnya dalam artian belum memiliki keahlian yang bersertifikat. Selain itu kondisi kapal patroli yang minim dan fasilitas yang kurang terawat.

3) Upaya yang dilakukan oleh Pangkalan Penjagaan Laut dan Pantai kelas II Tanjung Perak Surabaya untuk mengatasi kendala tersebut adalah dengan mengikutsertakan personil kapal dalam pelatihan diklat keterampilan, latihan gabungan, seminar, dan bimtek untuk menambah pengetahuan dan keahlian sesuai bidangnya. Selain itu, menjaga, memperbaiki, merawat, dan melengkapi secukupnya fasilitas kapal agar tetap baik kondisinya, melakukan pemeriksaan dan pembaharuan akan membantu dalam pengecekan kondisi kapal.

\section{DAFTAR PUSTAKA}

Aan Komariah dan Djam'an Satori. Metodologi Penelitian Kualitatif. Bandug: Alfabeta. 2017.

Hasan, Iqbal. 2002. Pokok-Pokok Materi Metodologi Penelitian dan Aplikasinya. Jakarta: Ghalia Indonesia.

Indrawan, Rulli, dan Yaniawati, Poppy. 2014. Metodologi Penelitian. Bandung: PT. Refika Aditama.

Moleong, dan Lexy J. 2012. Metodologi Penelitian Kualitatif. Bandung: PT. Remaja Rosdakarya.

Nana Syaodih Sukmadinata, Metode Penelitian Pendidikan, Bandung: PT. Remaja Rosdakarya, 2007.

Pickett, George \& Hanlon, John J. 2009. Kesehatan Masyarakat Administrasi dan Praktik, Jakarta : Buku Kedokteran EGC

Richard L.Daft, Era Baru Manajemen, Jakarta, Salemba Empat, Edisi ke 9.
Stephen P Robbins dan Mary Coulter, Manajemen Jakarta, PT. Prenhalindo, 1999, Edisi ke 6.

Sugiyono. 2009. Metode Penelitian Pendidikan Pendekatan Kuantitatif, Kualitatif, dan $R \& D$. Bandung: Alfabeta.

Sutopo. 2006. Metodologi Penelitian Kualitatif. Surakarta: UNS.

Tim Penyusun PIP Semarang. 2018. Buku Pedoman Penyusunan Skripsi. Semarang: Politeknik Ilmu Pelayaran Semarang.

Republik Indonesia, Undang-Undang No. 17 tahun 2008 tentang Pelayaran

Republik Indonesia, Peraturan Menteri Perhubungan No. 73 tahun 2017 tentang Peta Jabatan dan Uraian Jenis Kegiatan Jabatan di Lingkungan Unit Pelaksana Teknis Direktorat Jenderal Perhubungan Laut Kementerian Perhubungan.

Republik Indonesia, Keputusan Menteri Perhubungan No. 65 tahun 2002 tentang Organisasi dan Tata Kerja Pangkalan Penjagaan Laut dan Pantai. Republik Indonesia, Keputusan Menteri Perhubungan No. 60 tahun 2010 tentang Organisasi dan Tata Kerja Kementerian Perhubungan.

Republik Indonesia, Peraturan Direktur Jenderal Perhubungan Laut No. HK.205/8/13DJPL/2019 tentang Pedoman Teknis Kriteria Penempatan Kapal Negara Patroli Kesatuan Penjagaan Laut dan Pantai Direktorat Jenderal Perhubungan Laut.

Republik Indonesia, Keputusan Direktur

Jenderal Perhubungan Laut No.13/VI II/DV-05 tentang Wilayah Kerja Pangkalan Penjagaan Laut dan Pantai. Republik Indonesia, Keputusan Direktur Jenderal Perhubungan Laut No. KL.006/1/8/DJPL-13 tentang Pedoman Penyusunan Rencana Operasi Kapal Patroli Kesatuan Penjagaan Laut dan Pantai 